\title{
Research on the Mechanism of Digital Economy Driving the High- quality Development of Manufacturing
}

\author{
Bo Wang ${ }^{1}$ \\ ${ }^{1}$ School of Economics, Harbin University of Commerce, China
}

\begin{abstract}
This paper is based on the digitalization and manufacturing high-quality development indicators of the national and 30 provinces and municipalities from 2001 to 2017 to conduct research. The results show that the popularization and application of digital technology can significantly promote the high-quality development of the manufacturing industry. In view of this, this article proposes to vigorously develop the digital economy and put forward related industrial policy support, etc., to maximize the promotion effect of the digital economy on the high-quality development of the manufacturing industry.
\end{abstract}

\section{Introduction}

At present, China's economy has entered a new era characterized by the transition from a stage of rapid growth to a stage of high-quality development. In the new era, how to accelerate the deep integration of digital technologies such as the Internet and the real economy represented by the manufacturing industry, promote industrial technological transformation and optimization and upgrade, and promote the fundamental improvement of manufacturing industry models and development quality has become an important strategic issue for national development.

\section{The Mechanism Analysis on the Digital Economy Promoting the High- quality Development of Manufacturing}

2.1 Optimize the efficiency of resource allocation. Through digital transformation, the manufacturing industry can realize the automation and intelligentization of production and services, reduce the dependence on labor, reduce production costs, drive productivity increase, improve the allocation and utilization efficiency of manufacturing capital, labor and other production factors, and promote productivity improvement 1 .

2.2 Promote the upgrading of the industrial structure. Traditional manufacturing has obvious characteristics of agglomeration, giving full play to the advantages of clusters. With the rise of the Internet and other digital technologies, digital technology helps the manufacturing industry break the constraints of space, realize the virtual agglomeration of the manufacturing industry, and lay a solid foundation for the formation of manufacturing cluster innovation and industrial structure upgrading. Digital technology is continuously infiltrating the manufacturing industry, giving full play to the advantages of industrial collaborative innovation, and then realizing the transformation and upgrading of the manufacturing industry structure (2).

2.3 Enhance industry innovation capabilities. The digital economy has a diffusion effect. The integration and sharing of information resources increases the knowledge increment of innovative enterprises and produces a mapping effect. This innovative resource allocation transcends the limitations of physical space and realizes the rapid docking of resources in the economic system in the form of data transmission. The diversified innovation subjects in the industry form innovation clusters to accelerate industrial innovation (3).

2.4 Empower the green development of manufacturing. The in-depth integration of the digital economy and the manufacturing industry can trigger the emergence of new technologies and new production processes such as intelligent control technology in the manufacturing industry to achieve energy conservation and emission reduction. The intelligent environmental protection detection system used by the government and enterprises can also monitor in real time and help enterprises accurately discover and solve the problem of excessive emissions, thereby promoting the green development of the manufacturing industry (4).

2.5 Create a harmonious and shared atmosphere. The empowerment of the manufacturing industry by the digital economy will lead to the growth of the scale and output of the manufacturing industry, and the required jobs will increase year by year (the average annual growth of the 
population aged 15-64 is about $1.2 \%$, and the average annual growth of the number of people in the manufacturing industry is about $3 \%$ ). If the total number remains unchanged, the increase in labor demand will inevitably lead to an increase in labor prices, thereby increasing the amount of laborers sharing the fruits of labor, and achieving the harmonious and shared development of the manufacturing industry ${ }^{(5)}$.

\section{The Index System and Empirical Analysis of High-Quality Development for Manufacturing Industry}

\subsection{Manufacturing high-quality development index system}

In accordance with the five aspects of the new development concept, this article combines the research results of relevant scholars to formulate the following high-quality development indicator system for the manufacturing industry (see Table 1):

Table 1 High quality development index system of manufacturing industry

\begin{tabular}{|c|c|c|}
\hline First level composite index & Secondary composite index & Third level indicators \\
\hline \multirow{4}{*}{$\begin{array}{l}\text { Resource optimization and } \\
\text { development }\end{array}$} & Capital productivity & $\begin{array}{l}\text { Total output value of manufacturing industry / total investment in } \\
\text { manufacturing industry }\end{array}$ \\
\hline & labor productivity & $\begin{array}{l}\text { Total output value of manufacturing industry / total number of employees } \\
\text { in manufacturing industry }\end{array}$ \\
\hline & Energy productivity & $\begin{array}{l}\text { Total output value of manufacturing industry / total energy consumption } \\
\text { of manufacturing industry }\end{array}$ \\
\hline & cost-profit ratio & $\begin{array}{l}\text { Total profit of manufacturing industry / business cost of manufacturing } \\
\text { owner }\end{array}$ \\
\hline \multirow{4}{*}{$\begin{array}{l}\text { Structural upgrading and } \\
\text { development }\end{array}$} & Product export contribution & $\begin{array}{l}\text { Product export delivery value / total output value of manufacturing } \\
\text { industry }\end{array}$ \\
\hline & $\begin{array}{l}\text { Contribution of output value of high-tech } \\
\text { manufacturing industry }\end{array}$ & $\begin{array}{l}\text { Output value of high-tech manufacturing industry / total output value of } \\
\text { manufacturing industry }\end{array}$ \\
\hline & $\begin{array}{l}\text { Proportion of non-state-owned output } \\
\text { value }\end{array}$ & $\begin{array}{l}\text { Output value of non-state-owned enterprises / total output value of } \\
\text { manufacturing industry }\end{array}$ \\
\hline & $\mathrm{R} \& \mathrm{D}$ investment intensity & $R$ \& D expenses / total output value of manufacturing industry \\
\hline \multirow{4}{*}{$\begin{array}{l}\text { Scientific and technological } \\
\text { innovation and development }\end{array}$} & Per capita patent share & $\begin{array}{l}\text { Number of manufacturing patents / total number of manufacturing } \\
\text { employees }\end{array}$ \\
\hline & $\mathrm{R} \& \mathrm{D}$ intelligence input intensity & Number of R \& D personnel / total number of manufacturing employees \\
\hline & Revenue patent share & Main business income / number of effective invention patents \\
\hline & Exhaust emission per unit output value & $\begin{array}{l}\text { Exhaust emission of manufacturing industry / total output value of } \\
\text { manufacturing industry }\end{array}$ \\
\hline \multirow{5}{*}{$\begin{array}{l}\text { Green environmental } \\
\text { protection development }\end{array}$} & $\begin{array}{l}\text { Wastewater discharge per unit output } \\
\text { value }\end{array}$ & $\begin{array}{l}\text { Wastewater discharge of manufacturing industry / total output value of } \\
\text { manufacturing industry }\end{array}$ \\
\hline & $\begin{array}{l}\text { Proportion of environmental protection } \\
\text { investment }\end{array}$ & $\begin{array}{l}\text { Environmental protection equipment investment / total fixed assets } \\
\text { investment (output value) }\end{array}$ \\
\hline & $\begin{array}{l}\text { Penalty amount for environmental } \\
\text { protection }\end{array}$ & Amount of environmental punishment in the current month \\
\hline & $\begin{array}{l}\text { Years of education per capita (year/ } \\
\text { person) }\end{array}$ & $\begin{array}{l}\text { Total education years of manufacturing employees / total number of } \\
\text { manufacturing employees }\end{array}$ \\
\hline & Proportion of employees' wages & Total employee salaries / main business income \\
\hline \multirow{3}{*}{$\begin{array}{l}\text { Harmonious and shared } \\
\text { development }\end{array}$} & Per capita tax rate & Total tax paid / total number of employees \\
\hline & Strength of staff education and training & Staff education funds / main business income \\
\hline & Employee wage growth rate & Average wage growth rate \\
\hline
\end{tabular}

\subsection{Empirical analysis}

\subsubsection{Model building}

According to the aforementioned mechanism analysis, this paper sets the following benchmark model to verify the promotion effect of the digital economy on the highquality development of the manufacturing industry: HQi, $\mathrm{t}=\alpha 0+\alpha 1 \mathrm{DAi}, \mathrm{t}+\sum$ non Controli, $\mathrm{t}+\delta \mathrm{i}+\eta \mathrm{t}+\xi \mathrm{i}, \mathrm{t}$

Among them, $\mathrm{i}$ and $\mathrm{t}$ represent the sample area and period respectively, $\mathrm{HQ}_{\mathrm{i}, \mathrm{t}}$ refers to the manufacturing quality measured according to the indicator system, $\mathrm{DA}_{\mathrm{i}, \mathrm{t}}$ is the measured digital economy development level, Control $_{i, t}$ refers to the control variables, and $\delta_{\mathrm{i}}$ and $\eta_{\mathrm{t}}$ represent the region and Time effect respectively, $\xi_{\mathrm{i}, \mathrm{t}}$ is the random interference terms.

\subsubsection{Variable selection}

Based on the existing related research, aforementioned theoretical analysis and with availability of data 
considered, this paper, drawing on the method of Zhang Jun and others, measures the popularization and application level of China's inter-provincial digital economy mainly from the penetration rate on both telephone and the Internet. Based on the aforementioned indicator system and considering the availability of data, indicators are selected (see Table 2) to measure the manufacturing high-quality development index.

Table 2 High quality development index system of manufacturing industry

\begin{tabular}{|c|c|c|}
\hline $\begin{array}{l}\text { First level } \\
\text { composite } \\
\text { index }\end{array}$ & $\begin{array}{l}\text { Secondary composite } \\
\text { index }\end{array}$ & Third level indicators \\
\hline \multirow{2}{*}{$\begin{array}{c}\text { Resource } \\
\text { optimization } \\
\text { and } \\
\text { development }\end{array}$} & labor productivity & $\begin{array}{l}\text { Total manufacturing } \\
\text { income / total number of } \\
\text { manufacturing employees }\end{array}$ \\
\hline & cost-profit ratio & Profit / cost \\
\hline $\begin{array}{c}\text { Structural } \\
\text { upgrading and } \\
\text { development }\end{array}$ & $\begin{array}{l}\text { Contribution of output } \\
\text { value of high-tech } \\
\text { manufacturing } \\
\text { industry }\end{array}$ & $\begin{array}{l}\text { High tech manufacturing } \\
\text { income / total } \\
\text { manufacturing income }\end{array}$ \\
\hline \multirow{2}{*}{$\begin{array}{c}\text { Scientific and } \\
\text { technological } \\
\text { innovation and } \\
\text { development }\end{array}$} & $\begin{array}{l}\text { Proportion of sales } \\
\text { revenue of new } \\
\text { products }\end{array}$ & $\begin{array}{l}\text { New product sales } \\
\text { revenue / manufacturing } \\
\text { business revenue }\end{array}$ \\
\hline & $\begin{array}{l}\text { Patent occupancy per } \\
\text { unit income }\end{array}$ & $\begin{array}{l}\text { Number of patents in } \\
\text { manufacturing industry / } \\
\text { income from } \\
\text { manufacturing industry }\end{array}$ \\
\hline $\begin{array}{c}\text { Green } \\
\text { environmental } \\
\text { protection } \\
\text { development }\end{array}$ & $\begin{array}{l}\text { Energy consumption } \\
\text { per unit revenue }\end{array}$ & $\begin{array}{l}\text { Total energy consumption } \\
\text { / manufacturing business } \\
\text { income }\end{array}$ \\
\hline $\begin{array}{c}\text { Harmonious } \\
\text { and shared } \\
\text { development }\end{array}$ & Per capita tax rate & $\begin{array}{l}\text { Total tax paid / total } \\
\text { number of employees }\end{array}$ \\
\hline
\end{tabular}

According to existing research, the control variables are investment (IN), government regulation (GI), human capital (HU), and opening to the outside world (OP). Among them, investment is expressed by the proportion of fixed asset investment in GDP, government regulation is expressed by the proportion of fiscal expenditure in GDP, human capital is expressed by the average years of education, the level of opening up is expressed by the proportion of total import and export in GDP. The above

Table 3 The effect of digital economy on high quality development of manufacturing industry

\begin{tabular}{|c|c|c|c|c|}
\hline variable & (1) & (2) & (3) \\
\hline DA & $0.422^{* * *}(0.037)$ & $0.140^{* * *}(0.053)$ & $0.373^{* * *}(0.045)$ & $0.143(0.064)$ \\
\hline IN & & $0.018(0.040)$ & & \\
\hline GI & & $-0.215^{* * *}(0.031)$ & & \\
\hline HU & & $0.192^{* * *}(0.047)$ & & $0.255(0.030)$ \\
\hline OP & $0.088(0.064)$ & $0.140^{* * *}(0.020)$ & $0.138(0.23)$ & 0.188 \\
\hline Constant & 0.616 & $0.184(0.024)$ & 0.708 & 0.028 \\
\hline $\mathrm{R}$ & 0.376 & 0.771 & 0.494 & \\
\hline Adjusted R & & 0.586 & & \\
\hline
\end{tabular}

Note: robust standard errors are shown in brackets. $* * *, * *$, and $* *$ respectively indicated that they passed the test at the significance levels of $10 \%, 5 \%$, and $1 \%$.

\section{Policy suggestion}

\subsection{Accelerate the development of digital popularization applications}

indicator data comes from the China Information Yearbook, China Science and Technology Statistical Yearbook and related databases. The missing data is supplemented by interpolation and other methods.

\subsubsection{Regression analysis}

The data from 2011 to 2017 are used to perform a benchmark regression on equation (1). Column (1) of Table 3 shows the digital economy impact on the highquality development of the manufacturing industry. The result is positive and significant, indicating that the digital economy can promote the high-quality development of the manufacturing industry. In order to test the robustness of the above conclusions, control variables have been added to the column (2) of Table 3 . The comparison found that the core explanatory variable coefficients have declined, indicating that there are missing explanatory variables in the regression model without considering the control variables, but at this time the regression coefficients of the digital economic variables are still significant, indicating that the conclusion is still valid after adding other relevant variables.

Due to the large regional economic differences in China, this article returns to the eastern and central and western provinces respectively. The specific results are shown in columns (3) and (4) of Table 3 . The results show that the digital economy in the eastern region has a positive effect on the high-quality development of the manufacturing industry, while the central and western regions are not. This shows that there are regional differences in the impact of the digital economy on the high-quality development of the manufacturing industry. The digital economy has a prominent impact on the highquality development of the manufacturing industry in regions with a high degree of digitalization, but has no obvious impact on regions with a relatively low level of digitalization. 
economies, including manufacturing to Step forward.

\subsection{Guide the manufacturing industry to improve innovation capabilities}

Manufacturing enterprises should be well-guided to make full use of the advantages of the digital economy to reduce innovation costs, make full use of the specificity and particularity of knowledge, so as to improve the level of achievement transformation and extend the innovation chain of enterprises. At the same time, the policy should be tilted to the industrialization of innovation results, and provide a good platform for the docking of scientific and technological innovation results with products, markets, enterprises, and capital.

\subsection{Standardize the green development of the manufacturing industry}

A pointed setting of environmental regulations. Reasonable and relatively strict environmental regulations will crowd out low-efficiency and high-polluting companies as a result of cost-effects, so that the original rough workshops will be actively guided and cultivated into sophisticated small high-end Enterprises, while increasing the innovation capacity and industrialization of manufacturing enterprises, strengthen energy output rate, optimize the level of resource utilization, promote the balanced and healthy development of manufacturing industry, and realize a win-win pattern of economic development and environmental protection.

\subsection{Supporting policies help the development of the manufacturing industry}

In addition to supervision and guidance, a supporting government assistance policy should also be established to improve the accuracy and intensity of assistance, and help manufacturing enterprises make full use of the advantages of new technologies such as the digital economy to make up for their shortcomings and achieve sustainable development of higher quality and inclusiveness.

\section{References:}

1. Chuangzhong Du, Yuan Zhang. Research on the Influence Mechanism of the Development of the Digital Economy on the Growth of Enterprise Productivity.J. Securities Market Herald,2021, (02) :41-51.

2. Xiaoyun Zhang, Jiejiao Liu, Bin Li. Environmental Regulation, Technological Innovation and Green Development of Manufacturing Industry. J. Journal of Guangdong University of Finance and Economics. 2020,35 (05) :48-57.

3. Pingfeng Liu, Wang Zhang. How digital technology can empower manufacturing's total factor productivity.J. Science Research

4. Jun Wen, Zhijun Yan, Yu Cheng, Research on the effect of digital economy driving innovation Regression based on inter-provincial panel data.J. Economic reform 2020, (03) :31-38.

5. Yunhong Shen, Heng Huang. Research on the Impact of Digital Economy Level on the Optimization and Upgrading of Manufacturing Industry StructureBased on Zhejiang Province 2008-2017 panel data.J. Science and Technology Management Research,2020,40 (03) : 147-154. 